\title{
Potential factors that influence usage of complementary and alternative medicine worldwide: a systematic review
}

\author{
Mayuree Tangkiatkumjai ${ }^{{ }^{*}}$ (D) Helen Boardman² and Dawn-Marie Walker ${ }^{3}$
}

\begin{abstract}
Objectives: To determine similarities and differences in the reasons for using or not using complementary and alternative medicine (CAM) amongst general and condition-specific populations, and amongst populations in each region of the globe.

Methods: A literature search was performed on Pubmed, ScienceDirect and EMBASE. Keywords: 'herbal medicine' OR 'herbal and dietary supplement' OR 'complementary and alternative medicine' AND 'reason' OR 'attitude'. Quantitative or qualitative original articles in English, published between 2003 and 2018 were reviewed. Conference proceedings, pilot studies, protocols, letters, and reviews were excluded. Papers were appraised using valid tools and a 'risk of bias' assessment was also performed. Thematic analysis was conducted. Reasons were coded in each paper, then codes were grouped into categories. If several categories reported similar reasons, these were combined into a theme. Themes were then analysed using $x^{2}$ tests to identify the main factors related to reasons for CAM usage.
\end{abstract}

Results: 231 publications were included. Reasons for CAM use amongst general and condition-specific populations were similar. The top three reasons for CAM use were: (1) having an expectation of benefits of CAM ( $84 \%$ of publications), (2) dissatisfaction with conventional medicine (37\%) and (3) the perceived safety of CAM (37\%). Internal health locus of control as an influencing factor was more likely to be reported in Western populations, whereas the social networks was a common factor amongst Asian populations $(p<0.05)$. Affordability, easy access to CAM and tradition were significant factors amongst African populations $(p<0.05)$. Negative attitudes towards CAM and satisfaction with conventional medicine (CM) were the main reasons for non-use $(p<0.05)$.

Conclusions: Dissatisfaction with CM and positive attitudes toward CAM, motivate people to use CAM. In contrast, satisfaction with CM and negative attitudes towards CAM are the main reasons for non-use.

Keywords: Conventional medicine, Complementary and alternative medicine, Use, Not use, Factor

\footnotetext{
*Correspondence: mayureet@g.swu.ac.th

'Department of Clinical Pharmacy, Faculty of Pharmacy, Srinakharinwirot

University, Nakhonnayok 26120, Thailand

Full list of author information is available at the end of the article
}

(c) The Author(s). 2020 Open Access This article is licensed under a Creative Commons Attribution 4.0 International License, which permits use, sharing, adaptation, distribution and reproduction in any medium or format, as long as you give appropriate credit to the original author(s) and the source, provide a link to the Creative Commons licence, and indicate if changes were made. The images or other third party material in this article are included in the article's Creative Commons licence, unless indicated otherwise in a credit line to the material. If material is not included in the article's Creative Commons licence and your intended use is not permitted by statutory regulation or exceeds the permitted use, you will need to obtain permission directly from the copyright holder. To view a copy of this licence, visit http://creativecommons.org/licenses/by/4.0/. The Creative Commons Public Domain Dedication waiver (http://creativecommons.org/publicdomain/zero/1.0/) applies to the data made available in this article, unless otherwise stated in a credit line to the data. 


\section{Background}

Use of complementary and alternative medicine (CAM) has become widespread in the last two decades. The prevalence of CAM use in general populations worldwide ranges from $9.8 \%$ to $76 \%$ [1]. Twelve systematic reviews report reasons for CAM use mainly in cancer populations compared to other condition-specific populations [2-5].

Five of the systematic reviews aimed to determine reasons for CAM use in either general or condition-specific populations [2, 5-8]. The reviews reported that the main reasons for CAM use were: (a) expected benefits and perceived safety of CAM, (b) control and participation in their therapy, and (c) alignment of socioculture, beliefs and needs. The other six reviews also reported reasons for CAM use, but this issue was not their main aim $[3,4,9-12]$. Their findings showed various reasons for CAM use, such as: (1) the benefits and safety of CAM, (2) availability and accessibility of CAM, (3) influence from friends, family, and the mass media, and (4) dissatisfaction with conventional medicine $(\mathrm{CM})$. One systematic review from sub-Saharan Africa also reported barriers to CAM use that included: (a) the absence of conclusive scientific evidence for CAM, (b) a lack of belief in safety and efficacy of CAM, and (c) unhygienic practice in product preparation [9].

A narrative review (Jones et al., 2019) aimed to determine factors influencing CAM use in Australia and reported that cancer and other condition-specific populations shared some reasons for CAM use: (a) selfperceived ill health, (b) sense of well-being and (c) integrative treatment [13].

However these reviews do not directly compare similarities and differences in the reasons for CAM use between populations. There are also limited systematic reviews reporting reasons for not using CAM. The present review aimed to provide comprehensive understanding of factors influencing different populations to use/not use CAM.

\section{Methods}

The Preferred Reporting Items for Systematic Reviews and Meta-Analyses (PRISMA) 2009 statement was employed in the present systematic review [14]. Research questions of this review were 1) What were the similarities and differences in reasons for using/not using CAM amongst general and condition specific populations? and 2) What were the similarities and differences in reasons for using/not using CAM amongst populations in each region?

\section{Search strategy}

The databases - PubMed: National Library of Medicine, ScienceDirect and EMBASE were searched. It is recommended that two or more databases are searched. EMBASE alone has the highest percentage recall of papers and, as a result, gains in searching resources beyond EMBASE are modest [15-17]. Keywords used were 'herbal medicine' OR, 'herbal and dietary supplement' OR, 'complementary and alternative medicine', AND 'reason' OR 'attitude'. Free-text terms combined with Boolean operators and filters were used for searching relevant studies [18]. For example, 'complementary and alternative medicine' AND 'reason'; 'complementary and alternative medicine' AND 'attitude'. All permutations of these key words were performed. Herbal medicine and dietary supplements were used as keywords due to these products being extensively used worldwide, compared to other types of CAM [19-25]. Pubmed and EMBASE were chose because they are the main sources suggested by the Cochrane centre and provide relevant studies in this field [26]. Meanwhile, the ScienceDirect database has published information relating to the social sciences A date range of January 2003 to December 2018 was set as the World Health Organization's (WHO) 2002 definition of CAM was used to underpin this research: "CAM are used to refer to a broad set of health care practices that are not part of a country's own tradition, or not integrated into its dominant health care system" [27]. This current review began in 2019 and has reviewed relevant sources published ovevr a 15 year period from 2003 to 2018.

\section{Selection criteria}

Original articles published in English from 2003 to 2018 were reviewed. Quantitative, and qualitative studies, and mixed-methods research were included as each type of publication provided a different informational perspective and complemented each other. No limits were set regarding country of origin or type of population. This process was conducted by two independent reviewers.

\section{Exclusion criteria}

Conference proceedings, pilot studies, study protocols, letters, literature reviews or systematic reviews were excluded. The studies which did not report on factors or reasons for using, or not using, CAM were excluded. Furthermore, papers which studied some specific groups were also excluded, i.e. students, medical professionals, pregnant women, people aged less than 15 years, care givers, or specific sexual identities or ethnic groups. This exclusion was due to the premise that each group has a specific characteristic which may underpin their reasons for CAM usage, which may deviate from other populations. As the present review focused on the reasons and attitudes influencing people to use/not use CAM, efficacy trials of CAM were also excluded. 


\section{Data extraction and risk of bias assessment}

The process of extracting data from publications was conducted by two independent reviewers. Any disagreements were resolved by discussion with a third reviewer. The included quantitative studies were appraised using a standard tool adapted from Gan's study, which contained 10 items and assessed a study's internal and external validity [22]. Meanwhile, the qualitative studies were assessed by a standard tool from Jakes' study, which evaluated agreement between research questions, methods, representation, interpretation of results, influence of researchers, evidence of ethical approve and a flow from the analysis to conclusion [12]. These tools have been used for evaluating studies in the CAM field and seem to be appropriate to assessing the methodologies of the observational and qualitative studies included in this present systematic review.

\section{Data synthesis and statistical analysis}

Data in the present systematic review was analysed by both qualitative and quantitative methods conducted by two independent reviewers [28]. An inductive thematic approach was performed to identify themes of reasons for use and non-use of CAM [28]. All use or non-use reasons in each publication were coded by hand, and then grouped into a category according to the reason(s). If several categories reported similar reasons, such categories were combined into one theme. The themes, therefore, emerged from this process. This process was forward and backward analysed until the themes were consistent. Then, similarities and differences of the themes between general and condition-specific populations, and between Western and Asia populations were analysed by $x^{2}$-tests. Tests were two-tailed and a $p$-value $<0.05$ was considered statistically significant.

\section{Results}

Searching via the three databases provided 10,887 publications. After excluding irrelevant publications based on their title and abstract, 2,007 publications remained, from which 861 duplicates were removed. 799 publications met the exclusion criteria and were therefore not included. From the 347 full-text articles reviewed, 116 publications were excluded due to an absence of reporting factors or reasons for CAM use, resulting in 231

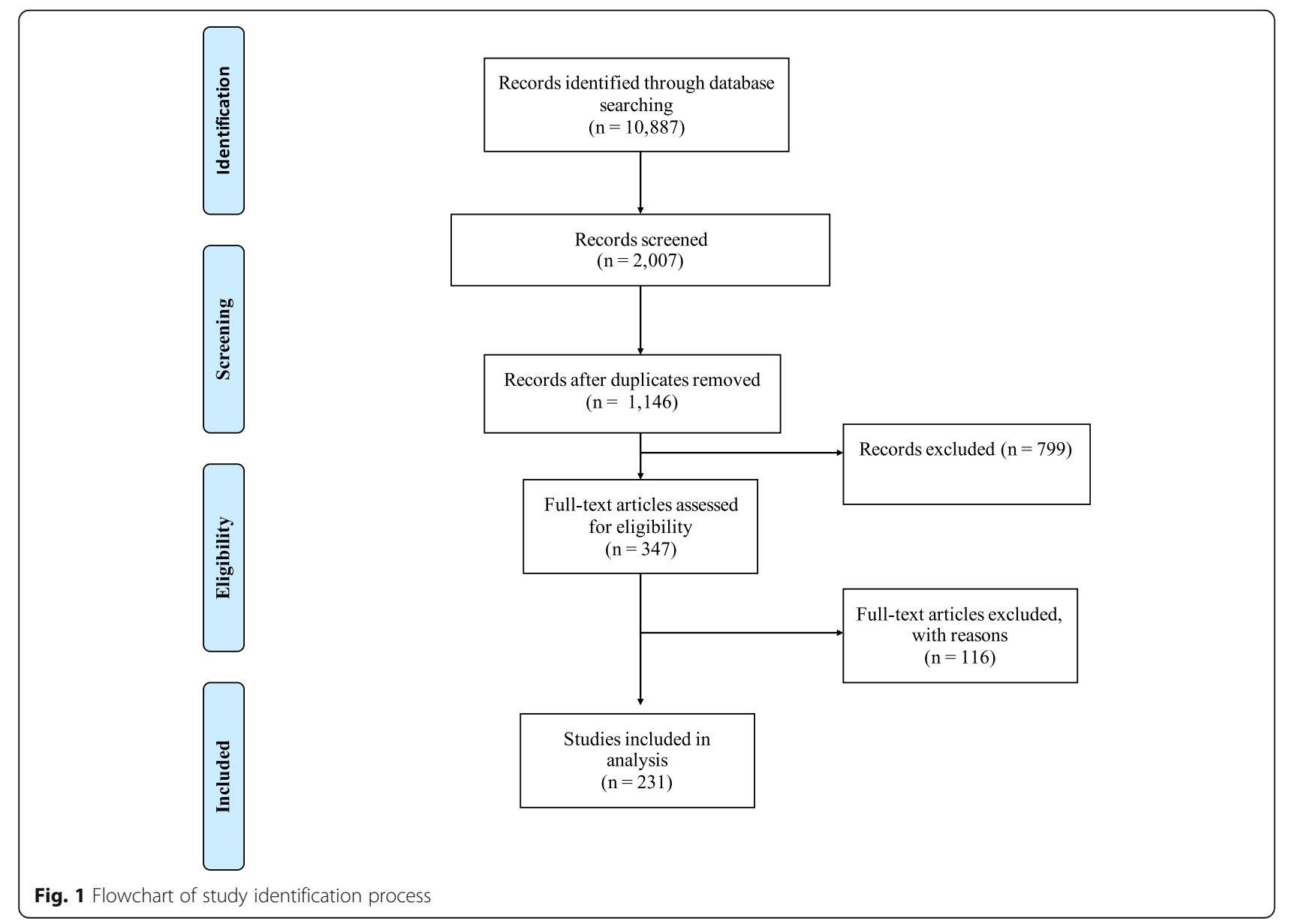


publications from 51 countries being included in the analysis (Fig. 1).

Thirty-seven out of the 231 included publications were qualitative studies (16\%) mainly from the United Kingdom (UK) [29-34], the United States (US) [35-38], Australia [39-41] or Canada [42-44]; a survey or crosssectional study were the most commonly employed quantitative methods in the included publications (80.5\%). Only eight mixed method papers (3.5\%) reported the reasons for CAM use [32, 45-51]. Eleven papers $(4.8 \%)$ were conducted in elderly populations $[35,39,42,43,52-58]$, and six $(2.6 \%)$ in women only populations [29, 38, 39, 59-61].

The highest number of all included publications originated in Asia (25.5\%), followed by Europe (20.9\%), North America (20.0\%) and the Middle East (14.7\%). A small number of publications from Australia were also included in the present systematic review (7.8\%).

To gather information the majority of the quantitative papers utilised questionnaires which provided a list of factors or reasons for using CAM based on previous studies. The majority of the included qualitative studies utilised interviews or focus groups with open-ended questions and employed thematic or inductive analyses. Sixty-four percent of the included publications defined CAM based on the National Center for Complementary and Alternative Medicine (NCCAM), the World Health Organization (WHO, 7\%), and the others, e.g. the Food and Drug Administration, the Dietary Supplement and Health Education Act (DSHEA), Ernst's definition, Eisenberg's definition, etc.

Figure 2 shows an increase in the number of publications related to reasons for CAM use amongst condition-specific populations since 2013, compared with publications involving general populations. The total number of publications dealing with CAM use amongst general and condition-specific populations in this review was $48(21 \%)$ and 179 (77\%), respectively. The number of the papers in condition-specific populations is higher than in general populations (Fig. 2), i.e. cancer (29.0\% of publications), diabetes (5.6\% of publications), cardiovascular disease and hypertension (5.2\% of publications), human immunodeficiency virus (HIV) (3.5\% of publications), inflammatory bowel disease $(3 \%$ of publications), pain ( $3 \%$ of publications), chronic kidney disease (2.6\% of publications), and depression $(0.9 \%$ of publications). The majority of studies in the present review reported various types of CAM use (69\%), followed by herbal medicine (18\%) and traditional medicine, including traditional Chinese medicine (1\%).

The risk of bias assessment resulted in one quantitative publication being excluded due to poor internal and external validity. The included studies addressing general populations had a low bias risk (mode of a total score $=$ 10 , range 7-10), and for condition-specific populations there was a moderate risk of bias (mode of a total score $=7$, range $5-10$ ). The weaknesses of studies involving condition-specific populations was mainly due to a lack of reporting of their randomisation procedure $(73 \%$ of the publications), how representative the sample was (64\%), and non-response bias (48\%). Details of the risk of bias assessment provided in a supplementary material no. 1.

Lack of reporting the researcher's background (69\% of the publications) and the influence of reseachers on the research $(60 \%)$ were the main weaknesses of the

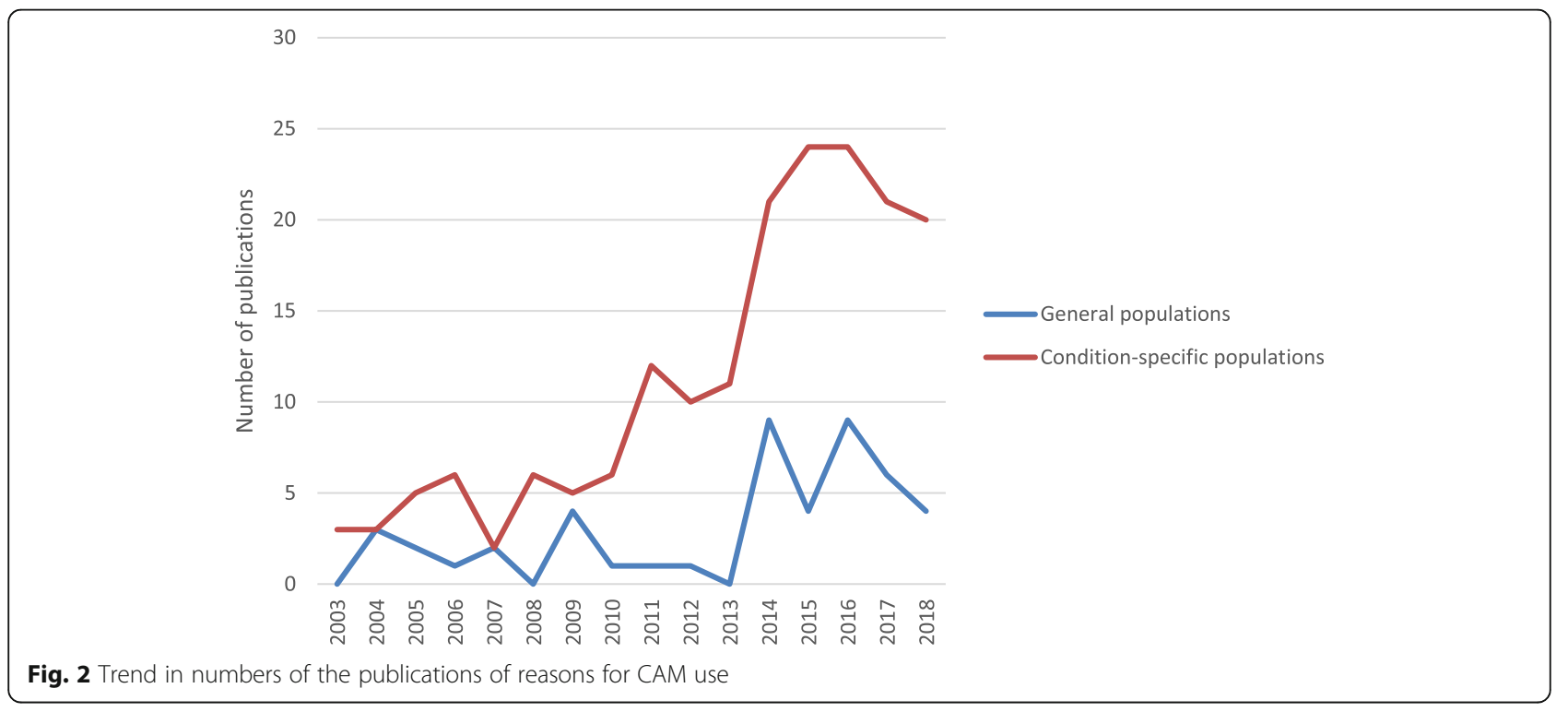


included qualitative studies in both general and condition-specific populations.

\section{Themes of reasons for use and non-use of CAM}

Both quantitative and qualitative studies reported similar reasons for CAM use. Thirty-three (14.3\%) publications provided reasons for use as well as non-use of CAM. The present systematic review found three main factors related to reasons for CAM use: positive attitudes toward CAM, negative attitudes toward $\mathrm{CM}$, and other factors, i.e. influence of their social network, their doctor's recommendation, having an internal health locus of control and tradition (Fig. 3). Reasons for non-use of CAM were having negative attitudes toward CAM and positive attitudes toward CM.

\section{Reasons for CAM use amongst general and condition- specific populations}

There was no difference in reasons for CAM use between general and condition-specific populations. The top three reported reasons for CAM use in all populations were perceived benefits (84\% of publications), and safety of CAM (37\%), and dissatisfaction with CM (37\%). The most reported expected benefits of CAM were treatment of illnesses, alleviation of symptoms, reducing side effects of CM, maintenance of well-being, or prevention of disease. People also reported that using CAM was a last resort [29, 44, 52, 62-64]. Improving physical and emotional well-being, and quality of life were further reasons for using CAM in patients with cancer [50, 63, 65-72]. The cancer patients also reported using CAM to reduce side effects of $\mathrm{CM}[33,45,65,66,69,73-80]$. Western populations in both the general and conditionspecific populations were more likely to report combining CAM and CM helped them [33, 54, 74, 81-84]. Likewise, condition-specific populations in some Asian and Middle East countries perceived that CAM complemented CM [63, 85-89]. Even though CAM is more likely to be a mainstream therapy in Asian countries, the Asian condition-specific populations tend not use CAM as a substitute for CM. However, $\mathrm{CM}$ is substituted with CAM amongst general populations in Japan [90].

Regarding dissatisfaction with $\mathrm{CM}$, being ineffective and/or causing side effects were the most frequently reported reasons in both general and condition-specific populations for their lack of satisfaction $[29,36,40,54$, 81, 87, 91-107]. Some patients wanted to use CAM in order to either avoid side effects resulting from $\mathrm{CM}$ or to decrease the number of conventional medicines taken $[49,92,103,108-112]$. A lack of trust in CM as the reason for using CAM was reported in three publications from Asia, two from the Middle East and one from Europe [61, 94, 113-116]. Additionally, condition-specific populations decided to use CAM to avoid invasive care or aggressive treatment [80,111]; or they were disappointed with or had negative experience of conventional care and/or the staff providing it $[41,80,86,97,103$, 105, 117-119]. CAM users in both Asian and Western populations preferred to visit CAM practitioners because

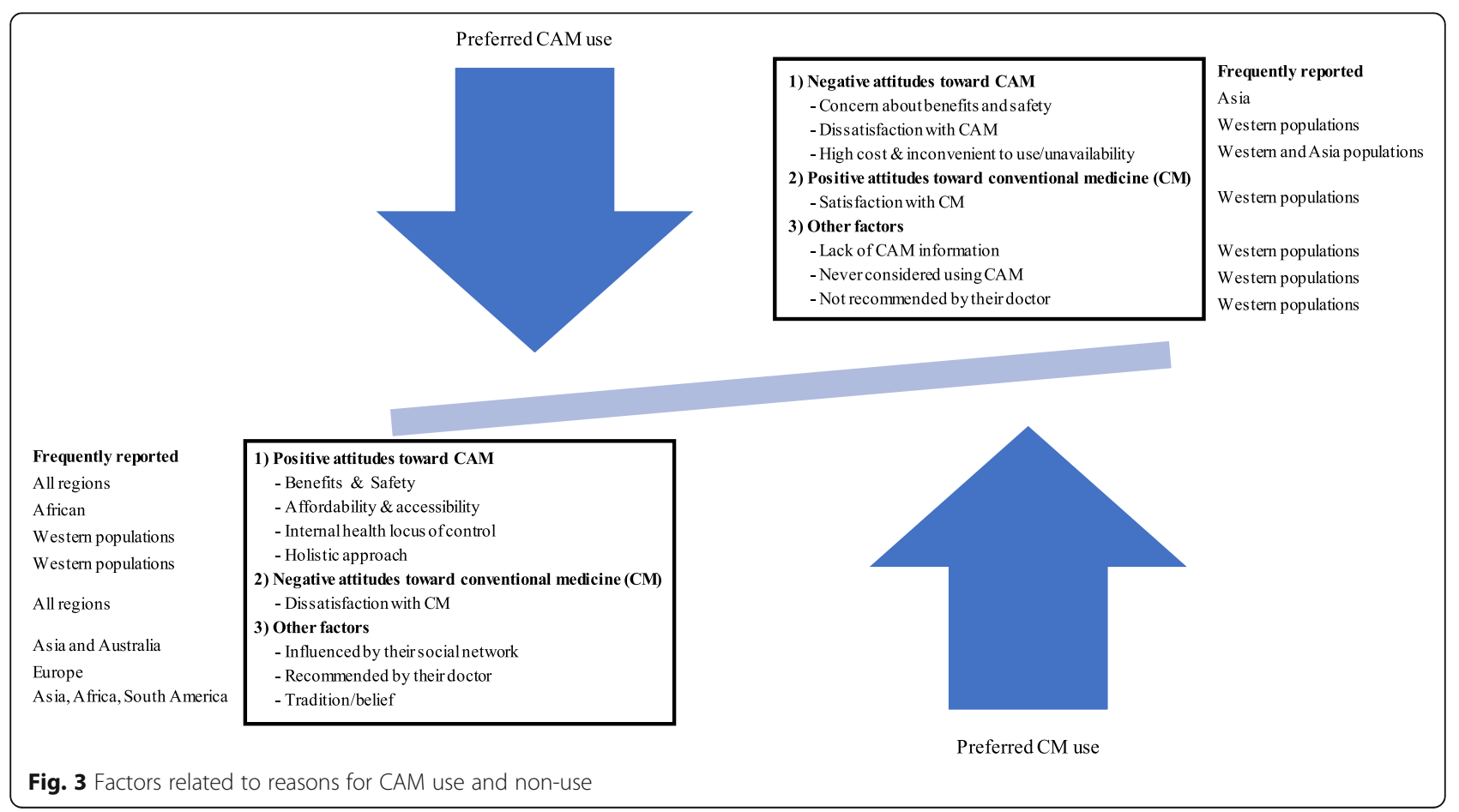


they provided fuller explanations and more time when compared with conventional health professionals [34, 66, 86]. Condition-specific populations in Asia and Africa often found it difficult to access $\mathrm{CM}$; a circumstance which drove them to use CAM [97, 120].

Only $8.7 \%$ of publications found that conditionspecific populations viewed CAM as natural, and thus safe $[21,29,49,65,67,76,92,100,106,107,112,114$, 121-129]. Six studies from Europe, Asia and Africa also reported 'being curious' as the reason for using CAM [92, 97, 130-133].

Other factors were influenced by CAM users' social networks (27\% of publications), having an internal health locus of control defined as preferring to control or decide choices of health treatments themselves (28\%), affordability of CAM (24\%), willingness to try or use CAM (including hope) (21\%), conventional health professionals' recommendation (18\%), easy access to CAM (14\%), belief in a holistic approach (12\%), and tradition/ belief (12\%). Internal health locus of control and a holistic approach were more likely to reported by Western populations, as such reasons may be developed from or informed by a Western perspective [30, 31, 34, 37, 42, $45,46,48,50,55,56,67,68,71,73,80,91,93,95,106$, $107,125-128,130,134-159]$.

\section{Similarities and differences in reasons for CAM use} amongst patients with cancer and other chronic illnesses The literature shows that patients with various illnesses share the main reasons for CAM use, such as perceived benefits of CAM use or dissatisfaction with CM rather than having different reasons in specific diseases [36, 40, $41,48,57,62,84,86,87,92,96,99,104,108,125,160-$
167]. However, being influenced by social media, having an internal health locus of control, or willingness to try CAM were reported more frequently by cancer patients than other members of condition-specific populations (Fig. 4). Meanwhile dissatisfaction with CM, affordability of CAM and easy access to CAM were more frequently reported by patients with other chronic illnesses $(p<$ 0.05). Patients with cancer, whilst accepting the efficacy and safety of CM, may use CAM in order to complement the efficacy of chemotherapy and/or reduce its unpleasant side effects (36\% of publications in cancer populations) $[33,34,45,63-67,69,71,73-79,88,122-$ $124,139,152]$.

\section{Reasons for CAM use in each region}

There was no global difference in the reported reasons for using CAM, namely the benefits of CAM, dissatisfaction with CM, and safety of CAM, see Fig. 5. However, the number of publications in Europe (35\% of publication), North America (48\%) and South America (75\%) that reported dissatisfaction with $\mathrm{CM}$ as the reason for using CAM was higher than in other populations. The benefits (89\% of publications) and safety of CAM (50\%) were reported as of the main reasons for CAM use in Australian populations.

An internal health locus control, affordability and easy access of CAM, as well as tradition/belief were significantly different in each region $(p<0.05)$. Internal health locus control influenced people in Australia (50\% of publications), South America (50\%), and Europe (48\%). Additionally, tradition significantly influenced CAM use in South America (38\% of publications), Africa (28\%) and Asia (17\%), compared with other regions. A high

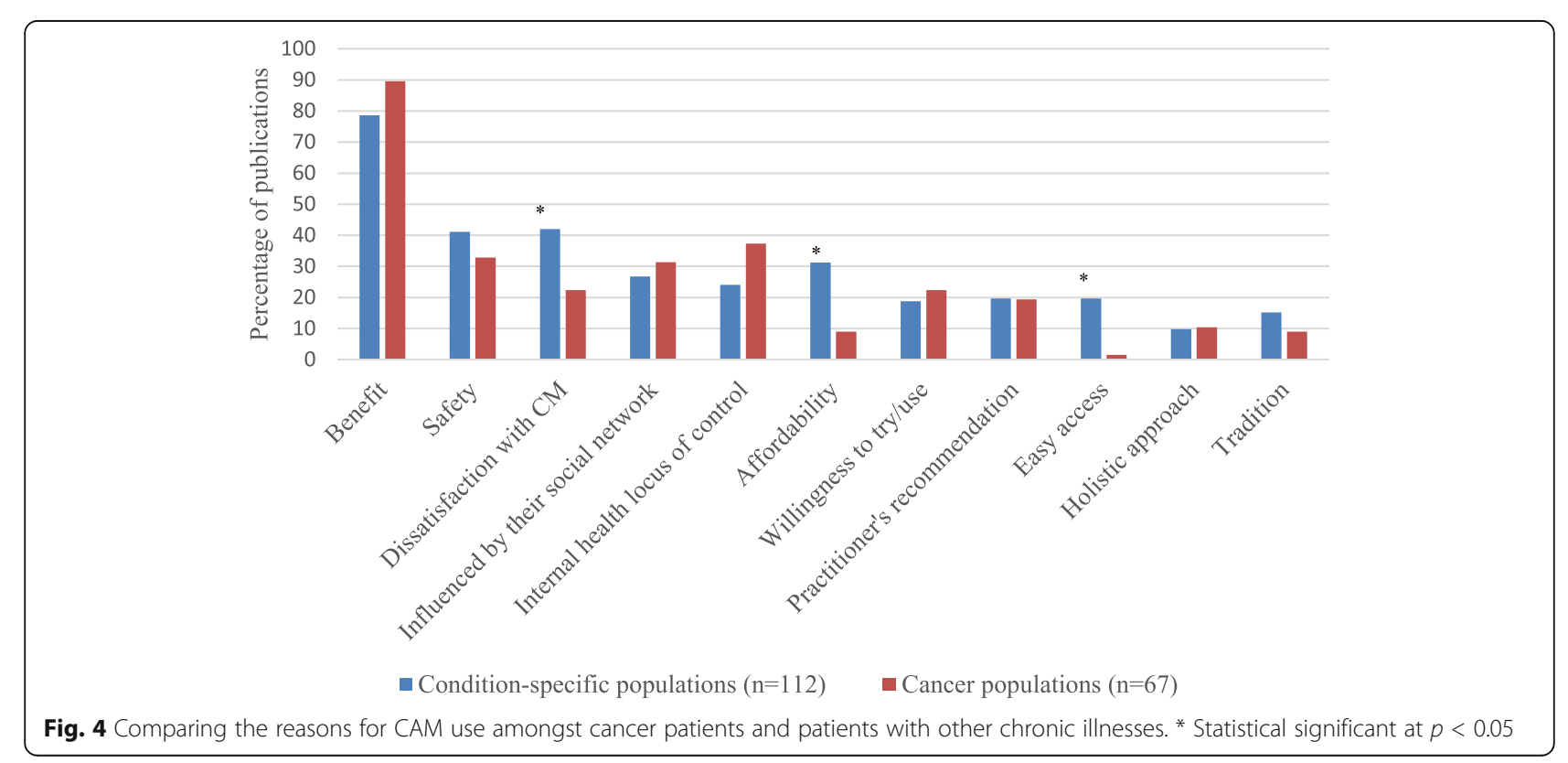




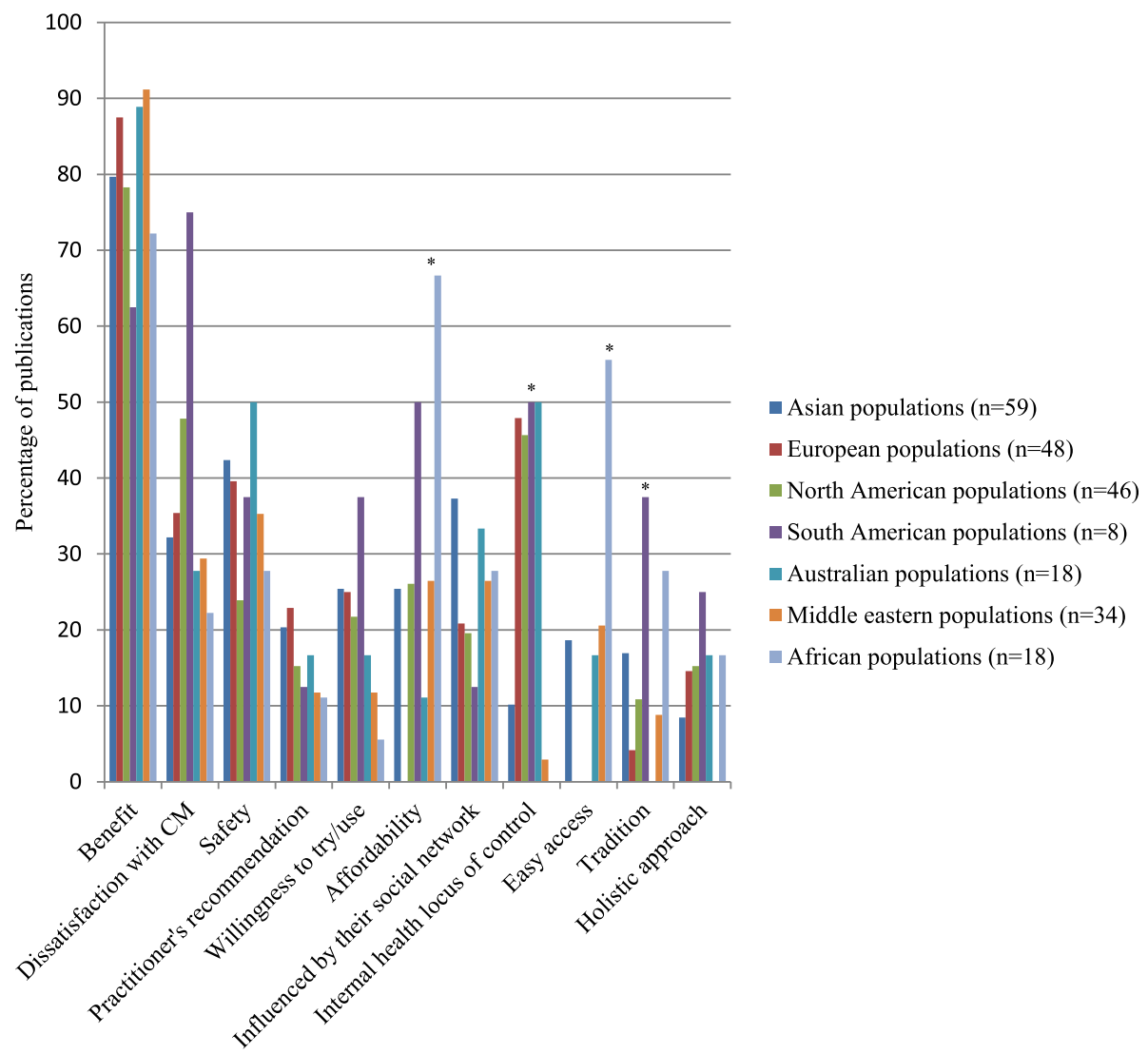

Fig. 5 Comparison of the reasons for CAM use worldwide. * Statistical significant at $p<0.05$

proportion of publications in Asian (37\%) and Australian populations $(33 \%)$ reported that social networks influenced them to use CAM, compared with other regions. African populations had the highest proportion of reported affordability of CAM (67\%) and easy access (56\%) as reasons for CAM use, whilst no report of these reasons was found in European populations. European populations (23\% of publications) are more likely to report conventional health professionals' recommendations for CAM use as their reason, compared with other regions.

Regarding reasons for CAM use amongst Western and Asian populations, Asian populations more frequently reported using CAM due to being influenced by members of their social network, low costs of CAM, easier access to CAM and tradition than Western populations $(p<0.05)$, Fig. 6. Meanwhile, having an internal health locus of control is the main reason for CAM use in Western populations $(p<0.05)$.

\section{Reasons for non-use amongst Western and Asian populations}

The studies of reasons for non-use are limited compared to the reasons for using CAM, so comparison of the reasons for non-use in each region cannot be made. No publications from the Middle East or South America were included in the present systematic review. Two publications from Africa and Australia were included. The majority of studies in the included publications were conducted in Asia, Europe or North America. Therefore, we compared Asian and Western populations.

Thirty papers in condition-specific populations $[45,47,65$, $75,79,80,95,107,115,120,123,124,130,150,152,157$, $162,168-179]$, six in general populations [180-185], one publication involving elderly people [53] and one publication involving females [61] reported the reasons for not using CAM. Asian populations more frequently reported doubt about the efficacy of CAM or lower effectiveness of CAM compared to CM, concerns about side effects of CAM, and inconvenience or unavailability of CAM than did members of Western populations $(p<0.05)$, Fig. $7[47,75,79,120$, 170, 172, 174-177, 179-181]. Some publications in Asian populations also reported concern about CAM reducing the efficacy of CM as a reason for non-use [169, 170].

Meanwhile, Western populations mainly reported satisfaction with CM (45\% of publications, $p<0.05)$ or had never considered using CAM $(60 \%, p<0.05)[45,65,95$, 


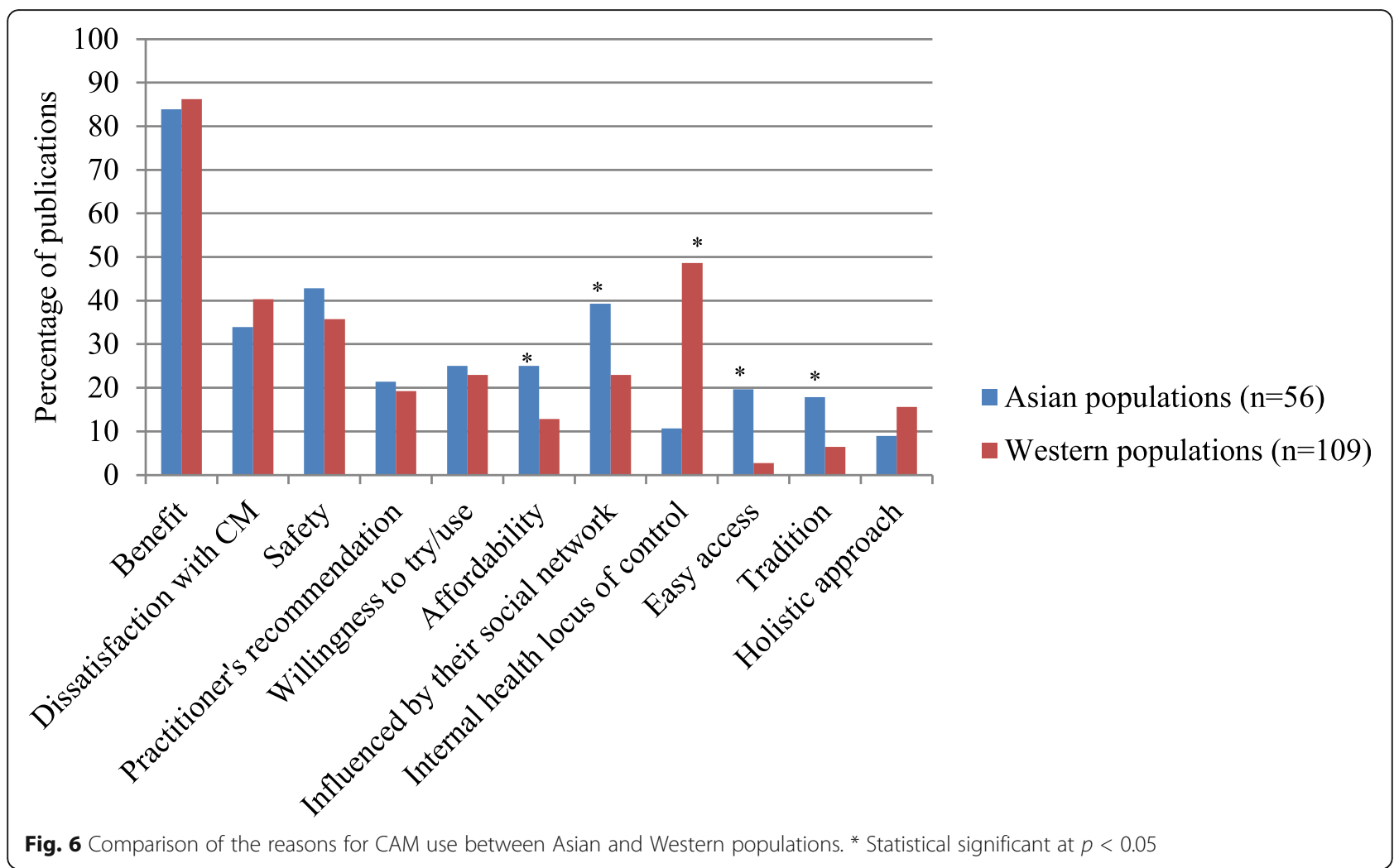

123, 124, 130, 150, 152, 157, 162, 171, 182, 184, 186].

Other reasons for the non-use of CAM were lack of reliable information about the efficacy of CAM, the high cost of CAM, and it not being recommended by conventional health professionals or the 'patient's' family.

\section{Discussion}

The included studies in the present systematic review can be seen to represent CAM use worldwide as they were mainly from Asia, Europe, North America, Middle East, and Australia. Recently, researchers in Asia have

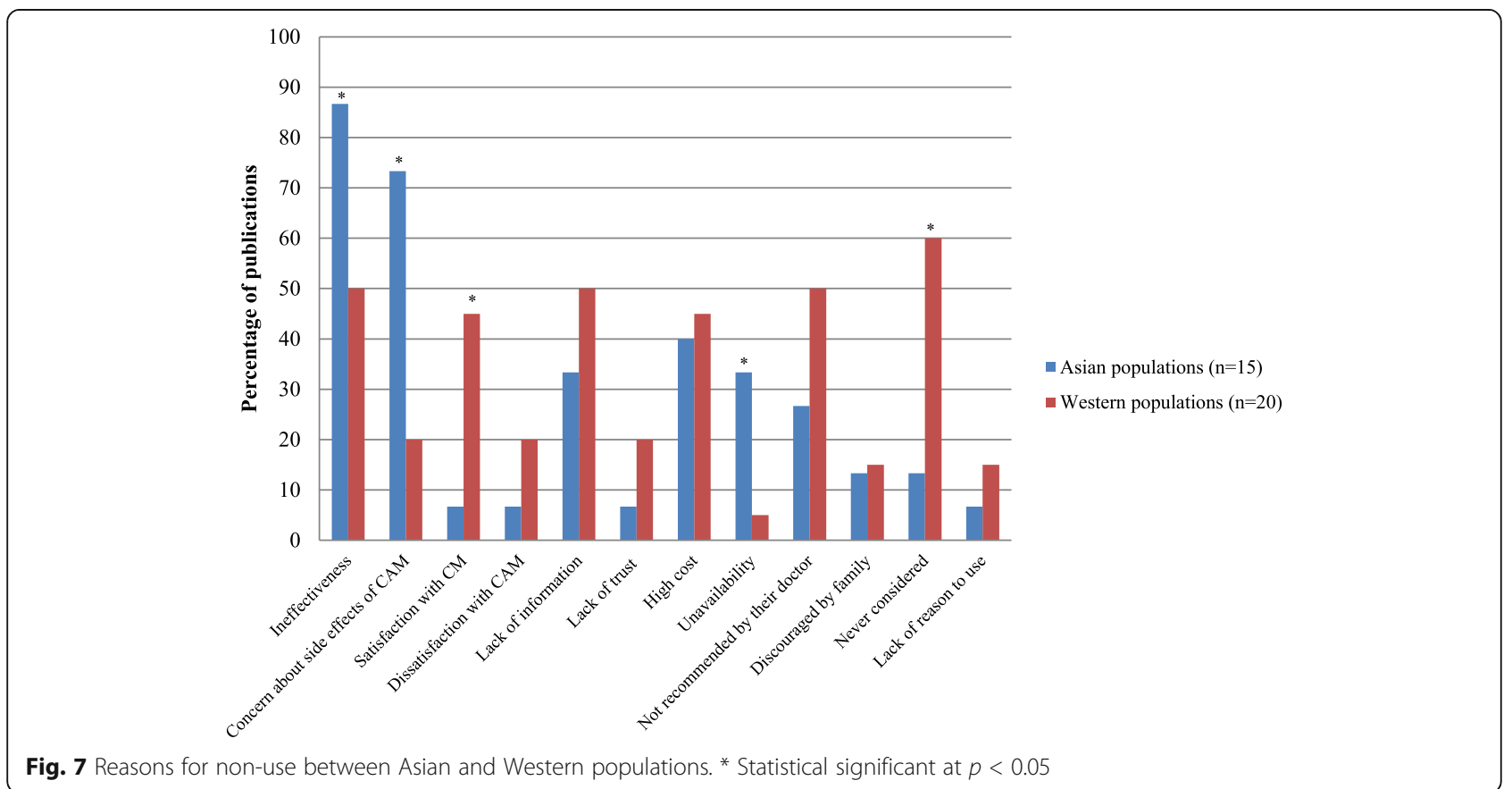


become interested in this field as several CAMs are embedded in their culture and society. Publications from this region has been rising since 2008; however, readers should be aware that the present systematic review included a small number of eligible publications from Australia and South America. Although a high number of publications originated in Australia, they tended to study specific populations, e.g. middle-aged women, and other topics, rather than reasons for CAM use. Researchers may less likely to investigate reasons for CAM use in South America, compared to other regions. Therefore, the findings in the present systematic review may be less likely to be generalisable in Australian and South American populations.

The present systematic review included a high number of publications amongst cancer, diabetic, cardiovascular disease, and HIV populations. It would therefore seem that illnesses, such as these which cannot be satisfactorily treated by $\mathrm{CM}$, or when CM has significant unpleasant side-effects, drive some patients to seek CAM. Cancer populations have been studied regarding reasons for CAM use more than other condition-specific populations. There are six systematic reviews of the reasons for CAM use in patients with cancer $[2,3,5,8,187,188]$.

As expected, three main factors related to reasons for CAM use in the present systematic review were positive attitudes toward CAM, negative attitudes toward CM and other factors, i.e. the influence of their social network, their doctor's recommendation, having an internal health locus of control and tradition. The top three reported reasons for CAM use were perceived benefits and safety of CAM, and dissatisfaction with CM. These findings are consistent with previous systematic reviews [3, 9-12]. These reasons are similar in both general and conditionspecific populations, and in populations from different global regions, as cited frequently above. Although the present systematic review included a limited number of publications from Australia, benefits and safety of CAM were reported as the main reasons for CAM use in Australian populations. These findings agree with a previous systematic review in Australia [6].

Despite limited scientific evidence for the benefits of CAM [189], the 'expected benefits' of CAM was the most frequently reported reason for CAM use. This finding is not surprising as people tend to seek CAM as a way of meeting their needs or filling a gap left by conventional medicine. The included publications amongst the cancer population are more likely to report CAM use for reducing the negative and often unpleasant side effects of CM. This finding is consistent with systematic reviews of CAM users with prostate or advanced cancer $[3,4]$. Additionally, the cancer population seems to accept the efficacy and side effects of $\mathrm{CM}$, and therefore uses CAM to complement CM.
Previously, people believed that CAM is natural and safe [190]. This idea may have led many patients with chronic illnesses on using CAM instead of CM. However, the present systematic review indicates that a small number of the included publications amongst conditionspecific populations reported that CAM is safe as a reason for CAM use. Therefore, CAM as natural therapy is not the main reason for CAM use; a point which may be linked to the high number of reported adverse events from using CAM [191-193]. Patients therefore should use CAM with caution or under supervision from conventional or CAM practitioners.

Regarding other factors related to CAM use in each region, nearly half of the included publications reported that internal health locus control influenced people in Australia, South America, and Europe. However, this reason may have been reported less by Asian, Middle Eastern and African people, as they may not explain their reasons in such terms. Tradition also significantly influenced CAM use in South America, Africa and Asia, compared with other global regions. This orientation may be because CAM, for example, herbal medicine, is embedded in such regions and therefore aligns with their populations' socio-culture values. Social networks influenced Asian and Australian populations to use CAM, compared with other regions, as they may have a closeknot family or community structure.

Affordability of CAM, together with easy access, are likely to be the main reasons for CAM use amongst African populations. The high cost of, and poor accessibility to, CM appears to influence people to use CAM in Africa [57, 58, 97, 164, 183, 194-201]. Meanwhile, no report of these reasons was found in European populations. CAM may not be cheap and easy to access in Europe, compared with $\mathrm{CM}$ as users have to personally pay for CAM and it can be difficult to access [19]. Moreover, European populations are more likely to report conventional health professionals' recommendations for CAM use as their reason for choosing that option, compared with other global regions. This option may be because health care is readily available in most European countries; so when they have a health problem, they visit their general practitioner.

There are limited publications reporting reasons for non-use of CAM in each region. Further studies relating to this issue are required, particularly in populations from Africa, the Middle East and South America. The present systematic review found that Asian populations are more likely to question the efficacy and safety of CAM, and to be concerned about potentially harmful interactions between herbal medicines and CM. These findings imply that Asian populations seem to understand the limitations of CAM, the efficacy and safety of CAM, and are aware of herb-drug interactions. 
The findings confirm that Western populations do not use CAM if they are satisfied with the efficacy and safety of CM. This outcome may be because they can easily access $\mathrm{CM}$, and CAM is less likely to be considered as an option for chronic illnesses in Western countries. However, if they were to become disappointed with the CM/ staff, they may decide to use CAM. This possibility is consistent with the systematic review of patients with cancer, which reported that the patients who were satisfied with CM did not use CAM [3]. Lack of reliable information about the efficacy of CAM, as a barrier to CAM use reported in the present systematic review, is consistent with the findings from a previous systematic review [9].

\section{Limitations of this review}

Although this review only selected a small number of key words, and only three search engines in order to search the literature the findings returned $43 \%$ duplicate publications. Further reviews should search using a wide range of CAM types as keywords, e.g. yoga, acupuncture, relaxation, etc., in order to confirm the findings from the present review. There was a small number of publications addressing the reasons for CAM use in South America $(\mathrm{n}=8)$; thus the findings from that continent should be interpreted with caution. This review included only publications in English; as a result the findings did not represent publications in other languages. Regarding the results from the search strategy used in this review, only $5 \%$ of the papers were excluded due to being nonEnglish. This outcome is unlikely to have any significant impact on the findings of the present review, as most of the studies were conducted in Europe, from where a high number of publications in English were identified for inclusion in this review.

Results of publications in condition-specific populations representing a national population should also be interpreted with caution due to only $36 \%$ of these studies being designed to represent the patient population. The present systematic review found poor external validity of the included studies amongst condition-specific populations, therefore future studies should be aware of this issue.

\section{Impact of the findings for conventional health professionals}

Expected benefits of CAM are the main reason for CAM use despite a lack of clinical trials. To promote the rational use of CAM, health care providers should be ready to provide such information to their patients and conventional medicine guidelines should report reliable information about CAM, and be easily available to, health care providers. The findings in the present review have confirmed that being disappointed with $\mathrm{CM}$ or associated professional providers, particularly in Western populations, is more likely to influence conditionspecific populations to use CAM. To prevent patients from using CAM inappropriately, health care providers should spend more time clearly explaining treatment options, the likely treatment outcomes and potential negative effects of CAM, including herb-drug interactions.

Having an internal health locus of control seems to be a main reason for CAM use in Western populations. This finding implies that patients prefer deciding a therapy by and for themselves. To decrease inappropriate use of CAM, conventional health care providers should offer sufficient health information to their patients, as well as holding a discussion with a patient, before deciding upon a health therapy.

A person's social network is more likely to influence their decision making regarding CAM in Asian populations. Therefore, health care providers should educate not only patients about how to properly use CAM, but also their friends and family members.

\section{Conclusions}

It is clear that the main reasons for CAM use in all populations are a positive attitude toward CAM, that is the perceived benefit and safety of CAM, and a negative attitude toward CM, a dissatisfaction with CM. Having an internal health locus of control is a more frequently reported reason for CAM use in Western populations, whilst being influenced by social networks is a common reason for its adoption amongst Asian populations. Affordability, easy access to CAM and tradition are the most common reasons amongst African populations. Negative attitudes towards CAM and satisfaction with $\mathrm{CM}$ are more likely to be the reason for non-use. Conventional health professionals should acknowledge that people may turn to CAM in order to serve their needs. Therefore, health care providers should regularly ask their patients about their use of CAM before that providers prescribes any conventional medicines, in order to prevent undesirable adverse effects or CAM-drug interactions. Further studies are required to investigate reasons for CAM use in South America and reasons for non-use in all global regions, in order to provide more conclusive evidence in this field.

\section{Supplementary Information}

The online version contains supplementary material available at https://doi. org/10.1186/s12906-020-03157-2.

Additional file 1. Risk of bias.

\section{Abbreviations}

CAM: Complementary and Alternative Medicine; CM: Conventional Medicine; HIV: Human Immunodeficiency Virus; PRISMA: The Preferred Reporting Items 
for Systematic Revews and Meta-Analyses; UK: The United Kingdom; US: The United States

\section{Acknowledgements}

Not applicable.

\section{Authors' contributions}

All the authors designed the study. MT and DW searched and extracted the publications. All the authors analysed, reviewed and approved the contents of the manuscript. MT drafted the manuscript. HB designed the study and analysed reviewed and approved the contents of the manuscript.

\section{Funding}

This research did not receive support from any funding agency in the public, commercial or not-for-profit sectors.

\section{Availability of data and materials}

The included publications in this systematic review were assessed their risk of bias in order to evaluate the quality of publications. This information provided in its supplementary information file. The other datasets used and analysed during the current study are available from the corresponding author on reasonable request.

\section{Ethics approval and consent to participate}

Not applicable

\section{Consent for publication}

Not applicable

\section{Competing interests}

The authors declare that they have no competing interests

\section{Author details}

${ }^{1}$ Department of Clinical Pharmacy, Faculty of Pharmacy, Srinakharinwirot University, Nakhonnayok 26120, Thailand. ²Division of Pharmacy Practice and Policy, School of Pharmacy, University of Nottingham, Nottingham, UK. ${ }^{3}$ School of Health Sciences, University of Southampton, Southampton, UK.

Received: 29 June 2020 Accepted: 12 November 2020

\section{Published online: 23 November 2020}

\section{References}

1. Harris PE, Cooper KL, Relton C, Thomas KJ. Prevalence of complementary and alternative medicine (CAM) use by the general population: a systematic review and update. Int J Clin Pract. 2012;66(10):924-39.

2. Weeks L, Balneaves LG, Paterson C, Verhoef M. Decision-making about complementary and alternative medicine by cancer patients: integrative literature review. Open Med. 2014;8(2):e54-66.

3. Truant $T L$, Porcino AJ, Ross BC, Wong ME, Hilario CT. Complementary and alternative medicine (CAM) use in advanced cancer: a systematic review. J Support Oncol. 2013;11(3):105-13.

4. Bishop FL, Rea A, Lewith H, Chan YK, Saville J, Prescott P. Elm Ev, Lewith GT. complementary medicine use by men with prostate cancer: a systematic review of prevalence studies. Prostate Cancer Prostatic Dis. 2011;14(1):1-13.

5. Verhoef MJ, Balneaves LG, Boon HS, Vroegindewey A. Reasons for and characteristics associated with complementary and alternative medicine use among adult cancer patients: a systematic review. Integr Cancer Ther. 2005; 4(4):274-86

6. Reid R, Steel A, Wardle J, Trubody A, Adams J. Complementary medicine use by the Australian population: a critical mixed studies systematic review of utilisation, perceptions and factors associated with use. BMC Complement Altern Med. 2016;16(1):176.

7. Franzel B, Schwiegershausen M, Heusser P, Berger B. Individualised medicine from the perspectives of patients using complementary therapies: a metaethnography approach. BMC Complement Altern Med. 2013;13:124.

8. Bishop FL, Yardley L, Lewith GT. A systematic review of beliefs involved in the use of complementary and alternative medicine. J Health Psychol. 2007; 12(6):851-67.

9. James PB, Wardle J, Steel A, Adams J. Traditional, complementary and alternative medicine use in sub-Saharan Africa: a systematic review. BM Glob Health. 2018;3(5):e000895.
10. Qureshi NA, Khalil AA, Alsanad SM. Spiritual and religious healing practices: some reflections from Saudi National Center for Complementary and Alternative Medicine, Riyadh. J Relig Health. 2018.

11. Yang $L$, Sibbritt $D$, Adams J. A critical review of complementary and alternative medicine use among people with arthritis: a focus upon prevalence, cost, user profiles, motivation, decision-making, perceived benefits and communication. Rheumatol Int. 2017;37(3):337-51.

12. Jakes $D$, Kirk R, Muir L. A qualitative systematic review of patients' experiences of acupuncture. J Altern Complement Med. 2014;20(9):663-71.

13. Jones E, Nissen L, McCarthy A, Steadman K, Windsor C. Exploring the use of complementary and alternative medicine in cancer patients. Integr Cancer Ther. 2019;18:1534735419854134.

14. Moher D, Liberati A, Tetzlaff J, Altman DG. Preferred reporting items for systematic reviews and meta-analyses: the PRISMA statement. BMJ. 2009; 339:b2535.

15. Bramer WM, Rethlefsen ML, Kleijnen J, Franco OH. Optimal database combinations for literature searches in systematic reviews: a prospective exploratory study. Syst Rev. 2017;6(1):245.

16. Halladay CW, Trikalinos TA, Schmid IT, Schmid CH, Dahabreh IJ. Using data sources beyond PubMed has a modest impact on the results of systematic reviews of therapeutic interventions. J Clin Epidemiol. 2015;68(9):1076-84.

17. Suarez-Almazor ME, Belseck E, Homik J, Dorgan M, Ramos-Remus C. Identifying clinical trials in the medical literature with electronic databases: MEDLINE alone is not enough. Control Clin Trials. 2000;21(5):476-87.

18. Keene MR, Heslop IM, Sabesan SS, Glass BD. Complementary and alternative medicine use in cancer: a systematic review. Complement Ther Clin Pract. 2019:35:33-47.

19. CAMbrella - A pan-European research network for Complementary and Alternative Medicine (CAM) [https://cordis.europa.eu/project/rcn/92501/ reporting/en]

20. Ock SM, Choi JY, Cha YS, Lee J, Chun MS, Huh CH, et al. The use of complementary and alternative medicine in a general population in South Korea: results from a national survey in 2006. J Korean Med Sci. 2009;24(1) $1-6$.

21. Singh V, Raidoo DM, Harries CS. The prevalence, patterns of usage and people's attitude towards complementary and alternative medicine (CAM) among the Indian community in Chatsworth, South Africa. BMC Complement Altern Med. 2004:4:3.

22. Gan WC, Smith L, Luca EJ, Harnett JE. The prevalence and characteristics of complementary medicine use by Australian and American adults living with gastrointestinal disorders: a systematic review. Complement Ther Med. 2018; 41:52-60.

23. Jatau Al, Aung MM, Kamauzaman TH, Chedi BA, Sha'aban A, Rahman AF. Use and toxicity of complementary and alternative medicines among patients visiting emergency department: systematic review. J Intercult Ethnopharmacol. 2016;5(2):191-7.

24. The Use of Complementary and Alternative Medicine in the United States [https://nccih.nih.gov/research/statistics/2007/camsurvey_fs1.htm].

25. Posadzki $P$, Watson LK, Alotaibi A, Ernst $E$. Prevalence of use of complementary and alternative medicine (CAM) by patients/consumers in the UK: systematic review of surveys. Clin Med (Lond). 2013;13(2):126-31.

26. Lefebvre C, Glanville J, Briscoe S, Littlewood A, Marshall C, Metzendorf M-I, et al. Searching for and selecting studies. Cochrane Handbook Syst Rev Interv. 2019:67-107.

27. World Health Organization. WHO traditional medicine strategy 2002-2005. Geneva: World Health Organization; 2002.

28. Gough D, Oliver S, Thomas J. An introduction to systematic reviews. 2nd ed. London: SAGE Publications Inc.; 2017.

29. Vickers KA, Jolly KB, Greenfield SM. Herbal medicine: women's views, knowledge and interaction with doctors: a qualitative study. BMC Complement Altern Med. 2006:6:40

30. Soundy A, Lee RT, Kingstone T, Singh S, Shah PR, Edwards S, et al. Experiences of healing therapy in patients with irritable bowel syndrome and inflammatory bowel disease. BMC Complement Altern Med. 2015;15:106.

31. Little CV. Simply because it works better: exploring motives for the use of medical herbalism in contemporary U. K, health care. Complement Ther Med. 2009;17(5-6):300-8

32. Holmes MM, Bishop FL, Calman L. "I just googled and read everything": exploring breast cancer survivors' use of the internet to find information on complementary medicine. Complement Ther Med. 2017:33:78-84. 
33. MacArtney Jl. Balancing exercises: Subjectivised narratives of balance in cancer self-health. Health (London). 2016;20(4):329-45.

34. de Valois B, Asprey A, Young T. "The monkey on your shoulder": a qualitative study of lymphoedema patients' attitudes to and experiences of acupuncture and moxibustion. Evid Based Complement Alternat Med. 2016; 2016:4298420.

35. Oberg EB, Thomas MS, McCarty M, Berg J, Burlingham B, Bradley R. Older adults' perspectives on naturopathic medicine's impact on healthy aging. Explore (NY). 2014;10(1):34-43.

36. Hwang JP, Roundtree AK, Suarez-Almazor ME. Attitudes toward hepatitis B virus among Vietnamese, Chinese and Korean Americans in the Houston area, Texa. J Community Health. 2012;37(5):1091-100.

37. Eaves ER, Sherman KJ, Ritenbaugh C, Hsu C, Nichter M, Turner JA, et al. A qualitative study of changes in expectations over time among patients with chronic low back pain seeking four CAM therapies. BMC Complement Altern Med. 2015;15:12.

38. Kabel A. Fighting for wellness: strategies of mid-to-older women living with cancer. J Cross Cult Gerontol. 2015;30(1):107-17.

39. McLaughlin D, Lui CW, Adams J. Complementary and alternative medicine use among older Australian women - a qualitative analysis. BMC Complement Altern Med. 2012;12:34.

40. Mclntyre E, Saliba AJ, Moran CC. Herbal medicine use in adults who experience anxiety: a qualitative exploration. Int J Qual Stud Health Wellbeing. 2015;10:29275.

41. Brijnath B, Antoniades J, Adams J. Investigating patient perspectives on medical returns and buying medicines online in two communities in Melbourne, Australia: results from a qualitative study. Patient. 2015;8(2):229-38.

42. Fries CJ. Older adults' use of complementary and alternative medical therapies to resist biomedicalization of aging. J Aging Stud. 2014;28:1-10.

43. Williamson AT, Fletcher PC, Dawson KA. Complementary and alternative medicine: use in an older population. J Gerontol Nurs. 2003;29(5):20-8.

44. Read SC, Carrier ME, Whitley R, Gold I, Tulandi T, Zelkowitz P. Complementary and alternative medicine use in infertility: cultural and religious influences in a multicultural Canadian setting. J Altern Complement Med. 2014;20(9):686-92.

45. Fox P, Butler M, Coughlan B, Murray M, Boland N, Hanan T, et al. Using a mixed methods research design to investigate complementary alternative medicine (CAM) use among women with breast cancer in Ireland. Eur J Oncol Nurs. 2013;17(4):490-7.

46. Niemi M, Stahle $\mathrm{G}$. The use of ayurvedic medicine in the context of health promotion--a mixed methods case study of an ayurvedic Centre in Sweden. BMC Complement Altern Med. 2016;16:62.

47. Tangkiatkumjai M, Boardman H, Praditpornsilpa K, Walker DM. Reasons why Thai patients with chronic kidney disease use or do not use herbal and dietary supplements. BMC Complement Altern Med. 2014;14:473.

48. Skovgaard L. Use and users of complementary and alternative medicine among people with multiple sclerosis in Denmark. Dan Med J. 2016;63(1): B5159.

49. Hendershot KA, Dixon M, Kono SA, Shin DM, Pentz RD. Patients' perceptions of complementary and alternative medicine in head and neck cancer: a qualitative, pilot study with clinical implications. Complement Therapies Clin Pract. 2014;20(4):213-8.

50. Scarton LA, Del Fiol G, Oakley-Girvan I, Gibson B, Logan R, Workman TE. Understanding cancer survivors' information needs and information-seeking behaviors for complementary and alternative medicine from short- to longterm survival: a mixed-methods study. J Med Libr Assoc. 2018;106(1):87-97.

51. Mulkins AL, McKenzie E, Balneaves LG, Salamonsen A, Verhoef MJ. From the conventional to the alternative: exploring patients' pathways of cancer treatment and care. J Complement Integr Med. 2016;13(1):51-64.

52. Levine MAH, Xu S, Gaebel K, Brazier N, Bedard M, Brazil K, et al. Self-reported use of natural health products: a cross-sectional telephone survey in older Ontarians. J Geriatr Pharmacother. 2009;7(6):383-92.

53. Cheung CK, Wyman JF, Halcon LL. Use of complementary and alternative therapies in community-dwelling older adults. J Altern Complement Med. 2007;13(9):997-1006.

54. Bruno JJ, Ellis JJ. Herbal use among US elderly: 2002 National Health Interview Survey. Ann Pharmacother. 2005;39(4):643-8.

55. Johnson PJ, Jou J, Rhee TG, Rockwood TH, Upchurch DM. Complementary health approaches for health and wellness in midlife and older US adults. Maturitas. 2016;89:36-42.
56. Murthy V, Sibbritt D, Broom A, Kirby E, Frawley J, Refshauge KM, et al. Back pain sufferers' attitudes toward consultations with CAM practitioners and self- prescribed CAM products: a study of a nationally representative sample of 1310 Australian women aged 60-65 years. Complement Ther Med. 2015; 23(6):782-8.

57. Ayele AA, Tegegn HG, Haile KT, Belachew SA, Mersha AG, Erku DA. Complementary and alternative medicine use among elderly patients living with chronic diseases in a teaching hospital in Ethiopia. Complement Ther Med. 2017;35:115-9.

58. Bayuo J. Experiences with out-patient hospital service utilisation among older persons in the Asante Akyem North District- Ghana. BMC Health Serv Res. 2017;17(1):652.

59. Faqueti A, Tesser CD. Use of complementary and alternative medicine in primary healthcare in Florianopolis, Santa Catarina, Brazil: user perception. Cien Saude Colet. 2018:23(8):2621-30.

60. Johnson PJ, Kozhimannil KB, Jou J, Ghildayal N, Rockwood TH. Complementary and alternative medicine use among women of reproductive age in the United States. Womens Health Issues. 2016;26(1): 40-7.

61. Mahmoudi GA, Almasi V, Lorzadeh N, Khansari A. The reasons for using and not using alternative medicine in Khorramabad women, west of Iran. J Pak Med Assoc. 2015;65(6):623-5.

62. Lambert TD, Morrison KE, Edwards J, Clarke CE. The use of complementary and alternative medicine by patients attending a UK headache clinic. Complement Ther Med. 2010;18(3-4):128-34.

63. Puataweepong P, Sutheechet N, Ratanamongkol P. A survey of complementary and alternative medicine use in cancer patients treated with radiotherapy in Thailand. Evid Based Complement Alternat Med. 2012; 2012:670408.

64. Ustundag S, Demir Zencirci A. Complementary and alternative medicine use among cancer patients and determination of affecting factors: a questionnaire study. Holist Nurs Pract. 2015;29(6):357-69.

65. Molassiotis A, Fernadez-Ortega P, Pud D, Ozden G, Scott JA, Panteli V, et al. Use of complementary and alternative medicine in cancer patients: a European survey. Ann Oncol. 2005;16(4):655-63.

66. Roberts D, Wilson C, Todd C, Long AF, Mackereth P, Stringer J, et al. Complementary therapies in cancer: patients' views on their purposes and value pre and post receipt of complementary therapy - a multi-Centre case study. Eur J Integr Med. 2013;5(5):443-9.

67. Hok J, Falkenberg T, Tishelman C. Lay perspectives on the use of biologically based therapies in the context of cancer: a qualitative study from Sweden. J Clin Pharm Ther. 2011;36(3):367-75.

68. Lengacher CA, Bennett MP, Kip KE, Gonzalez L, Jacobsen P, Cox C. Relief of symptoms, side effects, and psychological distress through use of complementary and alternative medicine in women with breast cancer. Oncol Nurs Forum. 2006;33(1):97-104.

69. Kremser T, Evans A, Moore A, Luxford K, Begbie S, Bensoussan A, et al. Use of complementary therapies by Australian women with breast cancer. Breast. 2008;17(4):387-94.

70. Al-Naggar RA, Bobryshev YV, Abdulghani M, Rammohan S, Osman MT, Kadir SYA. Complementay/alternative medicine use among cancer patients in Malaysia. World J Med Sci. 2013;8(2):157-64.

71. Helpman L, Ferguson SE, Mackean M, Rana A, Le L, Atkinson MA, et al. Complementary and alternative medicine use among women receiving chemotherapy for ovarian cancer in 2 patients populations. Int J Gynecol Cancer. 2011;21(3):587-93.

72. Sewitch MJ, Yaffe M, Maisonneuve J, Prchal J, Ciampi A. Use of complementary and alternative medicine by cancer patients at a Montreal hospital. Integr Cancer Ther. 2011;10(4):305-11.

73. Gillett J, Lentile C, Hiscock J, Plank A, Martin JM. Complementary and alternative medicine use in radiotherapy: what are patients using? J Altern Complement Med. 2012;18(11):1014-20.

74. Lövgren M, Wilde-Larsson B, Hök J, Leveälahti H, Tishelman C. Push or pull? Relationships between lung cancer patients' perceptions of quality of care and use of complementary and alternative medicine. Eur J Oncol Nurs. 2011;15(4):311-7.

75. Farooqui M, Hassali MA, Shatar AKA, Shafie AA, Seang TB, Farooqui MA. Complementary and alternative medicine (CAM) use by Malaysian oncology patients. Complement Ther Clin Pract. 2012;18(2):114-20. 
76. Xu W, Towers AD, Li P, Collet JP. Traditional Chinese medicine in cancer: perspectives and experiences of patients and professionals in China. Eur J Cancer Care. 2006;15(4):397-403.

77. Akyol AD, Oz B. The use of complementary and alternative medicine by patients with cancer: in Turkey. Complement Ther Clin Pract. 2011;17(4): 230-4.

78. Wong LYE, Leung PC, Tang JL, Mercer SW. Use of dietary supplements by breast cancer patients undergoing conventional cancer treatment. Patient Prefer Adherence. 2010;4:407-14.

79. Jaradat NA, Shawahna R, Eid AM, Al-Ramahi R, Asma MK, Zaid AN. Herbal remedies use by breast cancer patients in the West Bank of Palestine. J Ethnopharmacol. 2016;178:1-8.

80. Boon H, Brown JB, Gavin A, Westlake K. Men with prostate cancer: making decisions about complementary/alternative medicine. Med Decis Mak. 2003; 23(6):471-9.

81. Barnes PM, Powell-Griner E, McFann K, Nahin RL. Complementary and alternative medicine use among adults: United States, 2002. Adv Data. 2004; 343:1-19.

82. Yeh GY, Davis RB, Phillips RS. Use of complementary therapies in patients with cardiovascular disease. Am J Cardiol. 2006;98(5):673-80.

83. Kanodia AK, Legedza ATR, Davis RB, Eisenberg DM, Phillips RS. Perceived benefit of complementary and alternative medicine (CAM) for back pain: a national survey. J Am Board Fam Med. 2010;23(3):354-62

84. Jong MC, van de Vijver L, Busch M, Fritsma J, Seldenrijk R. Integration of complementary and alternative medicine in primary care: what do patients want? Patient Educ Couns. 2012;89(3):417-22.

85. Moolasarn S, Sripa S, Kuessirikiet V, Sutawee K, Huasary J, Chaisila C, et al. Usage of and cost of complementary/alternative medicine in diabetic patients. J Med Assoc Thail. 2005;88(11):1630-7.

86. Peleg R, Liberman O, Press Y, Shvartzman P. Patients visiting the complementary medicine clinic for pain: a cross-sectional study. BMC Complement Altern Med. 2011;11:36.

87. See A, Teo B, Kwan R, Lim R, Lee J, Tang MBY, et al. Use of complementary and alternative medicine among dermatology outpatients in Singapore. Australas J Dermatol. 2011;52(1):7-13.

88. Kang E, Yang EJ, Kim SM, Chung IY, Ah HS, Ku DH, et al. Complementary and alternative medicine use and assessment of qulity of life in Korean breast cancer patiens: a descriptive study. Support Care Cancer. 2012;20(3): 461-73.

89. Kamel FO, Magadmi RM, Hagras MM, Magadmi B, AlAhmad RA. Knowledge, attitude, and beliefs toward traditional herbal medicine use among diabetics in Jeddah Saudi Arabia. Complement Ther Clin Pract. 2017;29:20712.

90. Chiba T, Sato Y, Nakanishi T, Yokotani K, Suzuki S, Umegaki K. Inappropriate usage of dietary supplements in patients by miscommunication with physicians in Japan. Nutrients. 2014;6(12):5392-404.

91. Weizman AV, Ahn E, Thanabalan R, Leung W, Croitoru K, Silverberg MS, et al. Characterisation of complementary and alternative medicine use and its impact on medication adherence in inflammatory bowel disease. Aliment Pharmacol Ther. 2012;35(3):342-9.

92. D'Inca R, Garribba AT, Vettorato MG, Martin A, Martines D, Di Leo V, et al. Use of alternative and complementary therapies by inflammatory bowel disease patients in an Italian tertiary referral Centre. Dig Liver Dis. 2007;39(6): 524-9.

93. Brunelli B, Gorson KC. The use of complementary and alternative medicines by patients with peripheral neuropathy. J Neurol Sci. 2004;218(1-2):59-66.

94. Hasan SS, Ahmed SI, Bukhari NI, Loon WCW. Use of complementary and alternative medicine among patients with chronic diseases at outpatient clinics. Complement Ther Clin Pract. 2009;15(3):152-7.

95. Nayak S, Matheis RJ, Schoenberger NE, Shiflett SC. Use of unconventional therapies by individuals with multiple sclerosis. Clin Rehabil. 2003;17(2):181-91.

96. Zaman T, Agarwal S, Handa R. Complementary and alternative medicine use in rheumatoid arthritis: an audit of patients visiting a tertiary care Centre. Natl Med J India. 2007:20(5):236-9.

97. Olisa NS, Oyelola FT. Evaluation of use of herbal medicines among ambulatory hypertensive patients attending a secondary health care facility in Nigeria. Int J Pharm Pract. 2009;17(2):101-5.

98. Huri HZ, Lian GTP, Hussain S, Pendek R, Widodo RT. A survey amongst complementary alternative medicine (CAM) users with types 2 diabetes. Int J Diab Metab. 2009;17:9-15.
99. Purohit MP, Wells RE, Zafonte RD, Davis RB, Phillips RS. Neuropsychiatric symptoms and the use of complementary and alternative medicine. PM R. 2013;5(1):24-31.

100. Khalil SHA, Zaki A, Ibrahim AM, El-Moughazi AM, Khater AM, Youssef AM, et al. Pattern of use of complementary and alternative medicine among type 2 diabetes mellitus patients in Alexandria, Egypt. J Egypt Public Health Assoc. 2013;88(3):137-42.

101. Delgoda R, Younger N, Barrett C, Braithwaite J, Davis D. The prevalence of herbs use in conjunction with conventional medicines in Jamaica. Complement Ther Med. 2010;18(1):13-20.

102. Welz AN, Emberger-Klein A, Menrad K. Why people use herbal medicine: insights from a focus-group study in Germany. BMC Complement Altern Med. 2018;18(1):92.

103. Behnood-Rod A. Afzali poor Khoshkbejari M, Pourzargar P, Hassanzadeh M Moharamzad Y, Foroughi F: complementary and alternative medicine use among Iranian patients attending urban outpatient general practices. Complement Ther Clin Pract. 2018;30:58-63.

104. Bahall M, Edwards M. Perceptions of complementary and alternative medicine among cardiac patients in South Trinidad: a qualitative study. BMC Complement Altern Med. 2015;15:99.

105. Bahall M. Complementary and alternative medicine usage among cardiac patients: a descriptive study. BMC Complement Altern Med. 2015;15:100.

106. Bozza C, Gerratana L, Basile D, Vitale MG, Bartoletti M, Agostinetto E, et al. Use and perception of complementary and alternative medicine among cancer patients: the CAMEO-PRO study : complementary and alternative medicine in oncology. J Cancer Res Clin Oncol. 2018;144(10):2029-47.

107. Singh $H$, Maskarinec $G$, Shumay DM. Understanding the motivation for conventional and complementary/alternative medicine use among men with prostate cancer. Integr Cancer Ther. 2005;4(2):187-94.

108. Alshagga MA, AI-Dubai SA, Faiq SSM, Yusuf AA. Use of complementary and alternative medicine among asthmatic patients in primary care clinics in Malaysia. Ann Thorac Med. 2011;6(3):115-9.

109. Spanner ED, Duncan AM. Prevalence of dietary supplement use in adults with chronic renal insufficiency. J Ren Nutr. 2005;15(2):204-10.

110. Trangmar $P$, Diaz VA. Investigating complementary and alternative medicine use in a Spanish-speaking Hispanic community in South Carolina. Ann Fam Med. 2008;6(Suppl 1):s12-5.

111. Shmueli A, Shuval J. Use of complementary and alternative medicine in Israel: 2000 vs. Isr Med Assoc. 1993;6(1):3-8.

112. AlGhamdi KM, Khurrum H, Al-Natour SH, Alghamdi W, Mubki T, Alzolibani A, et al. Use of complementary and alternative medicine among dermatology outpatients: results from a national survey. J Cutan Med Surg. 2015;19(6):570-9.

113. Lim MK, Sadarangani P, Chan HL, Heng JY. Complementary and alternative medicine use in multiracial Singapore. Complement Ther Med. 2005;13(1):16-24.

114. Sawalha AF. Complementary and alternative medicine (CAM) in Palestine: use and safety implcations. J Altern Complement Med. 2007;13(2):263-9.

115. Portela F, Dias CC, Caldeira P, Cravo M, Deus J, Goncalves R, et al. The whowhen-why triangle of CAM use among Portuguese IBD patients. Dig Liver Dis. 2017:49(4):388-96

116. Al Akeel MM, Al Ghamdi WM, Al Habib S, Koshm M, Al Otaibi F. Herbal medicines: Saudi population knowledge, attitude, and practice at a glance. J Family Med Prim Care. 2018;7(5):865-75.

117. Bahall M. Prevalence, patterns, and perceived value of complementary and alternative medicine among HIV patients: a descriptive study. BMC Complement Altern Med. 2017;17(1):422.

118. Anbari K, Gholami M. Evaluation of trends in the use of complementary and alternative medicine in health centers in Khorramabad (west of Iran). Global J Health Sci. 2016;8(2):72-6.

119. Yonekura S, Okamoto $Y$, Sakurai $D$, Sakurai $T$, linuma $T$, Yamamoto $H$, et al. Complementary and alternative medicine for allergic rhinitis in Japan. Allergol Int. 2017;66(3):425-31.

120. Broom A, Wijewardena K, Sibbritt D, Adams J, Nayar KR. The use of traditional, complementary and alternative medicine in Sri Lankan cancer care: results from a survey of 500 cancer patients. Public Health. 2010;124(4):232-7.

121. Caliskaner Z, Kartal O, Gulec M, Ozturk S, Erel F, Sener O, et al. Awareness of allergy patients about herbal remedies: a cross-sectional study of residents of Ankara, Turkey. Allergol Immunopathol (Madr). 2010;38(2):78-82.

122. Molassiotis A, Margulies A, Fernandez-Ortega P, Pud D, Panteli V, Bruyns I, et al. Complementary and alternative medicine use in patients with haematological malignancies in Europe. Complement Ther Clin Pract. 2005;11(2):105-10. 
123. Molassiotis A, Ozden G, Platin N, Scott JA, Fernandez-Ortega P, Milovics L, et al. Complementary and alternative medicine use in patients with head and neck cancers in Europe. Eur J Cancer Care. 2006;15(1):19-24.

124. Molassiotis A, Panteli V, Patiraki E, Ozden G, Platin N, Madsen E, et al. Complementary and alternative medicine use in lung cancer patients in eight European countries. Complement Ther Clin Pract. 2006;12(1):34-9.

125. Hung A, Kang N, Bollom A, Wolf JL, Lembo A. Complementary and alternative medicine use is prevalent among patients with gastrointestinal diseases. Dig Dis Sci. 2015;60(7):1883-8.

126. Dossett ML, Davis RB, Lembo AJ, Yeh GY. Complementary and alternative medicine use by US adults with gastrointestinal conditions: results from the 2012 National Health Interview Survey. Am J Gastroenterol. 2014;109(11): 1705-11.

127. Arentz S, Smith CA, Abbott JA, Bensoussan A. A survey of the use of complementary medicine by a self-selected community group of Australian women with polycystic ovary syndrome. BMC Complement Altern Med. 2014;14:472

128. Lert F, Grimaldi-Bensouda L, Rouillon F, Massol J, Guillemot D, Avouac B, et al. Characteristics of patients consulting their regular primary care physician according to their prescribing preferences for homeopathy and complementary medicine. Homeopathy. 2014;103(1):51-7.

129. Arslan C, Guler M. Alternative medicine usage among solid tumour patients receiving chemotherapy. Eur J Cancer Care (Engl). 2017;26(5):e12530.

130. Rossi P, Torelli P, Lorenzo CD, Sances G, Manzoni GC, Tassorelli C, et al. Use of complementary and alternative medicine by patients with cluster headache: results of a multi-Centre headache clinic survey. Complement Ther Med. 2008;16(4):220-7.

131. Zhou F, Wu HJ, Zhai JP, Zhang GY, Shao Y, Tian X, et al. Who are the users of a traditional Chinese sanfu acupoint herbal patching therapy in China?: a cross-sectional survey. Medicine (Baltimore). 2016;95(49):e5414.

132. Koç Z, Çınarlı T. The determination of complementary and alternative medicine use in patients presenting at the emergency room. Complement Ther Clin Pract. 2018;31:164-9.

133. Loraschi A, Bellantonio P, Bortolon F, Capra R, Cavalla P, Costantino G, et al. Use of herbal remedies by multiple sclerosis patients: a nation-wide survey in Italy. Neurol Sci. 2016:37(4):613-22.

134. Kristoffersen AE, Stub T, Musial F, Fonnebo V, Lillenes O, Norheim AJ. Prevalence and reasons for intentional use of complementary and alternative medicine as an adjunct to future visits to a medical doctor for chronic disease. BMC Complement Altern Med. 2018;18(1):109.

135. Burke A, Lam CN, Stussman B, Yang H. Prevalence and patterns of use of mantra, mindfulness and spiritual meditation among adults in the United States. BMC Complement Altern Med. 2017;17(1):316

136. Thomson P, Jones J, Browne M, Leslie SJ. Why people seek complementary and alternative medicine before conventional medical treatment: a population based study. Complement Ther Clin Pract. 2014;20(4):339-46.

137. Huebner J, Muenstedt K, Prott FJ, Stoll C, Micke O, Buentzel J, et al. Online survey of patients with breast cancer on complementary and alternative medicine. Breast Care (Basel). 2014;9(1):60-3.

138. McCall M, Thorne S, Ward A, Heneghan C. Yoga in adult cancer: an exploratory, qualitative analysis of the patient experience. BMC Complement Altern Med. 2015;15:245.

139. Huebner J, Prott FJ, Micke O, Muecke R, Senf B, Dennert G, et al. Online survey of cancer patients on complementary and alternative medicine. Oncol Res Treat. 2014;37(6):304-8.

140. Upchurch DM, Rainisch BW. The importance of wellness among users of complementary and alternative medicine: findings from the 2007 National Health Interview Survey. BMC Complement Altern Med. 2015;15:362.

141. Mclntyre E, Saliba AJ, Wiener KKK, Bishop FL. Predicting the intention to use herbal medicines for anxiety symptoms: a model of health behaviour. J Ment Health. 2017:1-8.

142. Rhee TG, Westberg SM, Harris IM. Complementary and alternative medicine in US adults with diabetes: reasons for use and perceived benefits. J Diabetes. 2018;10(4):310-9.

143. Nguyen GC, Croitoru K, Silverberg MS, Steinhart AH, Weizman AV. Use of complementary and alternative medicine for inflammatory bowel disease is associated with worse adherence to conventional therapy: the COMPLIANT study. Inflamm Bowel Dis. 2016;22(6):1412-7.

144. Oxelmark L, Lindberg A, Lofberg R, Sternby B, Eriksson A, Almer S, et al. Use of complementary and alternative medicine in Swedish patients with inflammatory bowel disease: a controlled study. Eur J Gastroenterol Hepatol. 2016;28(11):1320-8.

145. Schmacke N, Muller $V$, Stamer M. What is it about homeopathy that patients value? And what can family medicine learn from this? Qual Prim Care. 2014; 22(1):17-24

146. Leach MJ, Lauche R, Zhang AL, Cramer H, Adams J, Langhorst J, et al. Characteristics of herbal medicine users among internal medicine patients: a cross-sectional analysis. J Herb Med. 2017;10:59-63.

147. Shorofi SA. Complementary and alternative medicine (CAM) among hospitalised patients: reported use of CAM and reasons for use, CAM preferred during hospitalisation, and the socio-demographic determinants of CAM users. Complement Ther Clin Pract. 2011;17(4):199-205.

148. Kuo GM, Hawley ST, Todd WL, Balkrishnan R, Volk RJ. Factors associated with herbal use among urban multiethnic primary care patients: a cross-sectional survey. BMC Complement Altern Med. 2004:4:18.

149. Hierl M, Pfirstinger J, Andreesen R, Holler E, Mayer S, Wolff D, et al. Complementary and alternative medicine: a clinical study in 1,016 hematology/oncology patients. Oncology. 2017;93(3):157-63.

150. Lettner S, Kessel KA, Combs SE. Complementary and alternative medicine in radiation oncology : survey of patients' attitudes. Strahlenther Onkol. 2017; 193(5):419-25.

151. Loquai C, Dechent D, Garzarolli M, Kaatz M, Kaehler KC, Kurschat P, et al. Use of complementary and alternative medicine: a multicenter cross-sectional study in 1089 melanoma patients. Eur J Cancer. 2017;71:70-9.

152. Kessel KA, Lettner S, Kessel C, Bier H, Biedermann T, Friess $H$, et al. Use of complementary and alternative medicine (CAM) as part of the oncological treatment: survey about patients' attitude towards CAM in a universitybased oncology Center in Germany. PLoS One. 2016;11(11):e0165801.

153. Salamonsen A. Use of complementary and alternative medicine in patients with cancer or multiple sclerosis: possible public health implications. Eur J Pub Health. 2016;26(2):225-9.

154. Wortmann JK, Bremer A, Eich HT, Wortmann HP, Schuster A, Fuhner J, et al. Use of complementary and alternative medicine by patients with cancer: a cross-sectional study at different points of cancer care. Med Oncol. 2016; 33(7):78.

155. King N, Balneaves LG, Levin GT, Nguyen T, Nation JG, Card C, et al. Surveys of cancer patients and cancer health care providers regarding complementary therapy use, communication, and information needs. Integr Cancer Ther. 2015;14(6):515-24

156. Salamonsen A. Mind the gap! Lay and medical perceptions of risks associated with the use of alternative treatment and conventional medicine. Forsch Komplementmed. 2015;22(1):24-9.

157. Sullivan A, Gilbar P, Curtain C. Complementary and alternative medicine use in cancer patients in rural Australia. Integr Cancer Ther. 2015;14(4):350-8.

158. Huebner J, Micke O, Muecke R, Buentzel J, Prott FJ, Kleeberg U, et al. User rate of complementary and alternative medicine (CAM) of patients visiting a counseling facility for CAM of a German comprehensive cancer center. Anticancer Res. 2014;34(2):943-8.

159. Egger S, Hughes S, Smith DP, Chambers S, Kahn C, Moxey A, et al. Factors associated with the use of complementary and alternative medicines for prostate cancer by long-term survivors. PLoS One. 2018;13(3):e0193686.

160. Osman NA, Hassanein SM, Leil MM, NasrAllah MM. Complementary and alternative medicine use among patients with chronic kidney disease and kidney transplant recipients. J Ren Nutr. 2015;25(6):466-71.

161. Tangkiatkumjai M, Boardman H, Praditpornsilpa K, Walker DM. Prevalence of herbal and dietary supplement usage in Thai outpatients with chronic kidney disease: a cross-sectional survey. BMC Complement Altern Med. 2013;13:153.

162. Wood MJ, Stewart RL, Merry H, Johnstone DE, Cox JL. Use of complementary and alternative medical therapies in patients with cardiovascular disease. Am Heart J. 2003;145(5):806-12.

163. Atwine F, Hultsjo S, Albin B, Hjelm K. Health-care seeking behaviour and the use of traditional medicine among persons with type 2 diabetes in SouthWestern Uganda: a study of focus group interviews. Pan Afr Med J. 2015;20:76

164. Haile KT, Ayele AA, Mekuria AB, Demeke CA, Gebresillassie BM, Erku DA. Traditional herbal medicine use among people living with HIV/AIDS in Gondar, Ethiopia: do their health care providers know? Complement Ther Med. 2017;35:14-9.

165. Fernandez A, Simian D, Quera R, Flores L, Ibanez P, Lubascher J, et al. Complementary and alternative medicine in patients with inflammatory 
bowel disease: a survey performed in a tertiary center in Chile. Complement Ther Med. 2018:40:77-82.

166. Basedow M, Runciman WB, March L, Esterman A. Australians with osteoarthritis; the use of and beliefs about complementary and alternative medicines. Complement Ther Clin Pract. 2014;20(4):237-42.

167. Siu JY. Coping with future epidemics: tai chi practice as an overcoming strategy used by survivors of severe acute respiratory syndrome (SARS) in post-SARS Hong Kong. Health Expect. 2016;19(3):762-72.

168. Jones D, Cohen L, Rieber AG, Urbauer D, Fellman B, Fisch MJ, et al. Complementary and alternative medicine use in minority and medically underserved oncology patients: assessment and implications. Integr Cancer Ther. 2018;17(2):371-9.

169. Sun L, Mao JJ, Vertosick E, Seluzicki C, Yang Y. Evaluating cancer patients' expectations and barriers toward traditional Chinese medicine utilization in China: a patient-support group-based cross-sectional survey. Integr Cancer Ther. 2018;17(3):885-93.

170. Chen G, Qiao TT, Ding H, Li CX, Zheng HL, Chen XL, et al. Use of Chinese herbal medicine therapies in comprehensive hospitals in Central China: a parallel survey in cancer patients and clinicians. J Huazhong Univ Sci Tech Med Sci. 2015;35(6):808-14.

171. Mani J, Juengel E, Arslan I, Bartsch G, Filmann N, Ackermann H, et al. Use of complementary and alternative medicine before and after organ removal due to urologic cancer. Patient Prefer Adherence. 2015;9:1407-12.

172. Nagashekhara M, Murthy V, Mruthyunjaya AT, Li Ann L. An empirical study on traditional, complementary and alternative medicine usage among Malaysian cancer patients. Asian Pac J Cancer Prev. 2015;16(15):6237-41.

173. Naja F, Fadel RA, Alameddine M, Aridi Y, Zarif A, Hariri D, et al. Complementary and alternative medicine use and its association with quality of life among Lebanese breast cancer patients: a cross-sectional study. BMC Complement Altern Med. 2015;15:444.

174. Lail G, Luck N, Tasneem AA, Rai A, Laeeq SM, Majid Z. The usage of complementary and alternative medicine in gastrointestinal patients visiting the outpatients' department of a large tertiary care Centre-views from Pakistan. Pan Afr Med J. 2016;24:247.

175. Lee K, Mokhtar HH, Krauss SE, Ong BK. Hypertensive patients' preferences for complementary and alternative medicine and the influence of these preferences on the adherence to prescribed medication. Complement Ther Clin Pract. 2014;20(2):99-105.

176. Chu FY, Yan X, Zhang Z, Xiong XJ, Wang J, Liu HX. Features of complementary and alternative medicine use by patients with coronary artery disease in Beijing: a cross-sectional study. BMC Complement Altern Med. 2013;12:287.

177. Leung GKK, Wong SWH, GKB N, Hung KN. Concomitant use of Western and Chinese medicine treatments in neurosurgical patients in Hong Kong. Chin J Integr Med. 2011; Epub ahead of print.

178. Richmond JA, Bailey DE, Patel K, Jezsik JA, Muir A, Lin JR, et al. The use of complementary and alternative medicine by patients with chronic hepatitis C. Complement Ther Clin Pract. 2010;16(3):124-31.

179. Saw JT, Bahari MB, Ang HH, Lim YH. Herbal use amongst multiethnic medical patients in Penang hospital: pattern and perceptions. Med J Malaysia. 2006;61(4):422-32

180. Jang S, Kim KH, Sun SH, Go HY, Lee EK, Jang BH, et al. Characteristics of herbal medicine users and adverse events experienced in South Korea: a survey study. Evid Based Complement Alternat Med. 2017;2017:4089019.

181. Yeong SW, Choong YC. Knowledge and characteristics of herbal supplement usage among community pharmacy customers in a Malaysian population. Complement Ther Med. 2017;35:92-108.

182. Burke A, Nahin RL, Stussman BJ. Limited health knowledge as a reason for non-use of four common complementary health practices. PLoS One. 2015; 10(6): 0129336

183. Lawrence D, Smith H, Magala E, Cooper M. Young people's opinions about herbal medicines in a suburban district of Central Uganda. Int Health. 2014; 6(4):337-8.

184. Upchurch DM, Rainisch BW. A sociobehavioral wellness model of acupuncture use in the United States, 2007. J Altern Complement Med. 2014;20(1):32-9.

185. Aziato L, Antwi HO. Facilitators and barriers of herbal medicine use in Accra, Ghana: an inductive exploratory study. BMC Complement Altern Med. 2016; 16:142.

186. Leong EM, Semple SJ, Angley M, Siebert W, Petkov J, McKinnon RA. Complementary and alternative medicines and dietary interventions in multiple sclerosis: what is being used in South Australia and why? Complement Ther Med. 2009;17(4):216-23.

187. Gratus C, Damery S, Wilson S, Warmington S, Routledge P, Grieve R, et al. The use of herbal medicines by people with cancer in the UK: a systematic review of the literature. Q J Med. 2009;102(12):831-42.

188. Eardley S, Bishop FL, Prescott P, Cardini F, Brinkhaus B, Santos-Rey K, et al. A systematic literature review of complementary and alternative medicine prevalence in EU. Forsch Komplementmed. 2012;19(Suppl 2):18-28.

189. Ernst E. How much of CAM is based on research evidence? Evid Based Complement Alternat Med. 2011;2011:676490.

190. Eisenberg DM, Kessler RC, Foster C, Norlock FE, Calkins DR, Delbanco TL, Unconventional medicine in the United States. Prevalence, costs, and patterns of use. N Engl J Med. 1993;328(4):246-52.

191. Haller CA, Kearney T, Bent S, Ko R, Benowitz NL, Olson K. Dietary supplement adverse events: reports of a one-year poison center surveillance project. J Med Toxicol. 2008;4(2):84-92.

192. Lee WJ, Kim HW, Lee HY, Son CG. Systematic review on herb-induced liver injury in Korea. Food Chem Toxicol. 2015;84:47-54.

193. Luyckx VA. Nephrotoxicity of alternative medicine practice. Adv Chronic Kidney Dis. 2012;19(3):129-41.

194. Belachew N, Tadesse T, Gube AA. Knowledge, attitude, and practice of complementary and alternative medicine among residents of Wayu town, Western Ethiopia. J Evid Based Complement Altern Med. 2017;22(4):929-35.

195. Bamidele JO, Adebimpe WO, Oladele EA. Knowledge, attitude and use of alternative medical therapy amongst urban residents of Osun state, southwestern Nigeria. Afr J Tradit Complement Altern Med. 2009:6(3):281-8.

196. Amaeze OU, Aderemi-Williams Rl, Ayo-Vaughan MA, Ogundemuren DA, Ogunmola DS, Anyika EN. Herbal medicine use among type 2 diabetes mellitus patients in Nigeria: understanding the magnitude and predictors of use. Int J Clin Pharm. 2018:40(3):580-8.

197. Lulebo AM, Mapatano MA, Mutombo PB, Mafuta EM, Samba G, Coppieters $Y$. Prevalence and determinants of use of complementary and alternative medicine by hypertensive patients attending primary health care facilities in Kinshasa, Democratic Republic of the Congo: a cross-sectional study. BMC Complement Altern Med. 2017;17(1):205.

198. Kretchy IA, Owusu-Daaku F, Danquah S. Patterns and determinants of the use of complementary and alternative medicine: a cross-sectional study of hypertensive patients in Ghana. BMC Complement Altern Med. 2014;14:44.

199. O'Neill S, Gryseels C, Dierickx S, Mwesigwa J, Okebe J, d'Alessandro U, et al. Foul wind, spirits and witchcraft: illness conceptions and health-seeking behaviour for malaria in the Gambia. Malar J. 2015;14:167.

200. Aboyade OM, Beauclair R, Mbamalu ON, Puoane TR, Hughes GD. Healthseeking behaviours of older black women living with non-communicable diseases in an urban township in South Africa. BMC Complement Altern Med. 2016;16(1):410

201. Agyei-Baffour P, Kudolo A, Quansah DY, Boateng D. Integrating herbal medicine into mainstream healthcare in Ghana: clients' acceptability, perceptions and disclosure of use. BMC Complement Altern Med. 2017: 17(1):513

\section{Publisher's Note}

Springer Nature remains neutral with regard to jurisdictional claims in published maps and institutional affiliations.

Ready to submit your research? Choose BMC and benefit from:

- fast, convenient online submission

- thorough peer review by experienced researchers in your field

- rapid publication on acceptance

- support for research data, including large and complex data types

- gold Open Access which fosters wider collaboration and increased citations

- maximum visibility for your research: over $100 \mathrm{M}$ website views per year

At $\mathrm{BMC}$, research is always in progress.

Learn more biomedcentral.com/submission 